Tér és Társadalom 20. évf. 2006/1. 147-158. p.

Tér és Társadalom

XX. évf. 2006

1: $147-163$

\title{
KÖNYVJELZÖ
}

\section{A TÖRTÉNELMI BELVÁROSOK TÁRSADALMI FENNTARTHATÓSÁGA KELET-KÖZÉP-EURÓPA VÁROSAIBAN}

\author{
Beszámoló a 2005 szeptemberében Székesfehérváron \\ megrendezett nemzetközi konferencia eredményeiről
}

\section{KERESZTÉLY KRISZTINA}

A tanulmány a MOST-UNESCO program keretében 2005 szeptemberében Székesfehérváron megrendezett nemzetközi konferencia eredményeit összegzi. A konferencia a kelet-közép-európai nagyvárosok történelmi belvárosainak sajátosságait vizsgálta esettanulmányok segítségével. A térség sajátos fejlödése mögött több tényezö húzódik: a történelmi események következtében a belvárosok fokozott identitás-válsága; a rendszerváltás következtében a bonyolult tulajdonviszonyok kialakulása és a magánszektor szerepének növekedése; a dzsentrifikáció kapcsán a társadalmi konfliktusok kialakulása, melyek feloldását hátráltatja a civil szektor gyengesége. Mindezen folyamatokat erösíti, hogy a demokratikus helyi igazgatás kialakítására törekvő törvénykezés széles kompetenciákkal, de csak korlátozott gazdasági lehetőségekkel rendelkezỏ helyi önkormányzatokat hozott létre a régióban. A magánszektor dominanciája néhány esetben szélsőséges gazdasági és politikai korrupcióhoz is vezet, ami méginkább felerösíti a történelmi belvárosok fizikai és társadalmi romlását.

A MOST-UNESCO Magyarországi Bizottsága az MTA/VITA Alapítvány, a Kodolányi János Föiskola és az MTA-RKK szervezésében 2005 szeptemberében nemzetközi konferenciát tartott Székesfehérváron. ' A konferencia célja volt, hogy megismertesse a történelmi belvárosok rehabilitációjával kapcsolatban Közép-Kelet Európa városaiban felmerülő jellegzetes problémákat, illetve az azokra adott várospolitikai megoldásokat. A konferenciára a városrehabilitációt különféle szempontok (szociológia, közigazgatás, várostervezés, városföldrajz) szerint vizsgáló magyar szakemberek mellett több kelet-közép európai országból hívtunk elóadókat ${ }^{2}$. A székesfehérvári konferencia az UNESCO „MOST” elnevezésủ nemzetközi kutatási programja keretében került megrendezésre, de eredményei nem egyedül e nemzetközi programot gazdagítják.

A kelet-közép európai városközpontok építészeti, társadalmi és gazdasági romlása a 20. század második felében, majd különösen a rendszerváltás után egyre meghatározóbb városfejlesztési, várospolitikai kérdéssé vált. A városrehabilitáció, sok esetben nyugat-európai példák nyomán már az 1980-as évek óta napirendre került a 
közép-kelet-európai régióban, ám az ekkor született elképzelések nagy része nem valósulhatott meg. Az évtized végén bekövetkezett rendszerváltás hirtelen és gyökeresen alakította át a városrehabilitáció társadalmi, gazdasági, politikai és városépítészeti feltételeit. A probléma ismét háttérbe szorult, és csupán az elmúlt években merült fel újra komplex várospolitikai kérdésként.

Az 1990-es évek gyors, ugyanakkor a városok életét sok esetben csak felszínesen érintő és javító gazdasági átalakulása számos társadalmi és környezeti konfliktus kialakulásához vezetett. Az ezredforduló környékén ebben a régióban is egyre nagyobb hangsúlyt, egyre összetettebb értelmezést kap a fenntartható városfejlődés fogalma. A „fenntartható városfejlödés”, „városrehabilitáció” vagy „revitalizáció" prioritásai nélkül ma már elképzelhetetlen egy városfejlesztési stratégia elfogadása. A városközpontok átalakulásával kapcsolatban ugyanakkor megjelenik a „dzsentrifikáció" fogalma. Milyen valós városi-társadalmi és városfejlesztési problémákat takarnak ezek a fogalmak a kelet-közép európai régióban? Kimutathatók-e közös kelet-közép-európai sajátosságok, melyek kezelésére esetleg a nyugateurópai mintáktól eltérő, helyi megoldásokat kellene keresnünk? A székesfehérvári konferencia célja volt, hogy az ott bemutatott esettanulmányok segítségével megvilágítsa és megértesse ezeket a közös pontokat, és azokat a várospolitika gyakorlati szakemberei számára értelmezhetővé tegye.

A konferencia elöadásaiból készült tanulmányok, további esettanulmányokkal kiegészítve, várhatóan 2006 első felében Magyarországon jelennek meg angol nyelven. Az esettanulmányokból levont következtetések, tanulságok pedig beépülnek a MOST-UNESCO magyarországi bizottsága által, az UNESCO felkérésére, 2006 közepére elkészülö, az UNESCO gondozásában megjelenő kézikönyvbe, melynek címe: 'A történelmi belvárosok társadalmi perspektívái' ('Social Perspectives of Historical Districts of Cities') lesz. E kézikönyv célja, hogy polgármesterek és városfejlesztési döntéshozók számára nyújtson gyakorlati tanácsokat a fenntartható városrehabilitációra vonatkozóan.

Az alábbi beszámoló az UNESCO „MOST” programjának ismertetése után, a konferencián elhangzott elöadások, illetve az azok alapján 2006. január elejéig elkészült kéziratok tanulságait összegzi.

\section{A MOST-UNESCO programról}

Az UNESO „MOST” (Management of Social Transformations (-A Társadalmi Átalakulások Kezelése) nevü hálózata tudományos és városfejlesztési szakemberek részvételével jött létre. $\mathrm{E}$ hálózat egyik programja a városok fenntartható társadalmi fejlödésével foglalkozik. Célja, hogy várospolitikusok és tudományos kutatók számára egyaránt felhasználható módon, nemzetközi összehasonlítások alapján mutassa be a városok társadalmi átalakulásának kezelésére alkalmas lehetséges várospolitikai módszereket. Az ENSZ HABITAT, a Világbank illetve egyéb nemzetközi szervezetek hasonló kutatási programjaihoz képest a MOST-UNESCO sajátossága, hogy elsősorban a városok helyi politikájára koncentrál, és legfontosabb célja, hogy a helyi 
Tér és Társadalom 20. évf. 2006/1. 147-163. p.

döntéshozók, polgármesterek számára nyújtson nemzetközi esettanulmányokon alapuló gyakorlati tanácsokat. A MOST-UNESCO kutatás első fázisa 1995-ben indult „A városok társadalmi fenntarthatósága" (Socially Sustainable Development of Cities) címmel, 11 város részvételével ${ }^{3}$. A programban minden város egy-egy, elméleti és gyakorlati szakemberekböl álló kutatócsoporttal vett részt. Az egyes városokat elemzö esettanulmányok elkészủlését több nemzetközi találkozó segítette. Az esettanulmányok alapján két kézikỏnyv született (Bailly et al. 2000). ${ }^{4}$

A MOST-UNESCO program 1998-ban zárult II. fázisát 1999 és 2001 között a III. fázis követte, „A közszféra részvétele a városok társadalmi fenntarthatóságában” (Public Participation in Socially Sustainable Urban Development) címmel. A MOSTUNESCO program III. fázisában 6 város $^{5}$ vett részt, házigazdája a budapesti csoport lett, Enyedi György vezetésével. 2004-ben az UNESCO támogatásával angol és francia nyelven Pécsett jelent meg a kutatást összefoglaló gyakorlati kézikönyv ${ }^{6}$.

2004-ben az UNESCO Humán és Társadalmi Tudományok Főosztálya úgy döntött, hogy folytatja a MOST-UNESCO program hagyományát, és némileg átalakított formában és tematikával egy újabb, a városok fenntartható társadalmi fejlödését célzó programot indít el. E program küldetése, hogy várospolitikai megoldásokat dolgozzon ki a világ különböző régióiban a történelmi városközpontok dzsentrifikációja ảltal okozott társadalmi, gazdasági, kulturális folyamatok ellensúlyozására, a társadalmi kirekesztés megakadályozása, a kulturális örökség védelmére, vagy a történelmi városrészek eredeti funkcióinak megörzésére. A ,Social Perspectives of Historical Districts of Cities" c. program a MOST programok elképzeléséhez hủen nemzetközi összehasonlításon alapszik, és célja egy gyakorlati kézikönyv kidolgozása polgármesterek számára. A MOST eddigi programjaitól eltérően azonban a 2004-ben kidolgozott elképzelés szerint a részt vevő kutatócsoportok nem csak saját városukat képviselik, hanem nagyobb, több országra kiterjedő földrajzi régiójukat is. Így a budapesti csoport a kelet-közép-európai régióban tapasztaltakat foglalja össze gyakorlati tanácsokat tartalmazó kézikönyv formájában. A kézikönyv a 2006-ban, Vancouverben megrendezésre kerülő ENSZ-Habitat konferencián kerül a nyilvánosság elé. A székesfehérvári konferencia eredményei ennek a kézikönyvnek az alapját jelentik.

A 2004-ben induló program hipotézise, hogy a napjainkban mind elterjedtebbé váló dzsentrifikáció jelensége, vagyis a leromló városközpontok, városrészek társadalmi, építészeti, gazdasági és funkcionális átalakulása, valamint a piacgazdaság igényei alapján történő revitalizációja számos negatív társadalmi hatása miatt megkérdőjelezendő és átgondolandó jelenség. Mivel a várostervezés módszereit a piacgazdaság feltételei között kell megfogalmazni, a dzsentrifikáció negatív hatásait sehol sem lehet teljes mértékben kiküszöbölni. A várospolitika elsödleges szempontja kell legyen azonban, hogy a város társadalmi élete, identitása, gazdasága, építészete szempontjából alapvetỏ szerepet játszó tơrténelmi városrészek, városközpontok fenntartható revitalizációját elősegítse. Csökkentse az új funkciók megjelenése okozta társadalmi, kulturális és gazdasági konfliktusok negatív hatásait, elósegítse az érintett negyedekben élő lakosság és az újonnan megjelenó társadalmi rétegek integrációját, együttélését, támogassa a városrész építészeti értékeinek megtartását, 
Tér és Társadalom 20. évf. 2006/1. 147-163. p.

megakadályozza a helyi hagyományok, ủzletek, szolgáltatások teljes eltünését, azok felváltását a világ akármelyik pontján megtalálható kávézókka! vagy uizletkőzpontokkal. A várospolitikának azonban az is feladata, hogy az egyre elöregedö, társadalmilag és építészetileg leromló városrészek dinamizálását elösegítse. E kettős, és egymásnak sok esetben nagyon is ellentmondó cél megértése, elemzése és a lehetséges módszerek kidolgozása ma a fenntartható társadalmi fejlődést szem elött tartó várospolitika egyik legaktuálisabb és egyben legnehezebb feladata. A székesfehérvári konferencia résztvevői saját városukról készített esettanulmányok bemutatásával a fenti kérdések elemzésére vállalkoztak.

\section{A történelmi belvárosok társadalmi fenntarthatósága - a konferencia tapasztalatai}

Az alábbi beszámoló a konferencián elhangzott előadások mellett az azok alapján elkészülỏ angol nyelvủ kötethez 2006. január elejéig már elkészült kéziratok alapján fogalmazódott meg. A kötetben szereplö esettanulmányok várhatóan a következő városokat fogják érinteni: Budapest, Bukarest, Kolozsvár, Krakkó, Pozsony, Prága, Zágráb, Varsó. A nem poszt-szocialista városokkal való összehasonlítás végett Bécs és Lyon szerepel majd.

Az előadások és cikkek alapján elsőként a probléma megközelitése, ill. a fogalomhasználat kérdése merül fel. A cikkek nagy részben az adott városokban tapasztalható, viszonylag új keletü dzsentrifikációs folyamatok leírására szorítkoznak. A dzsentrifikáció jelei ma már minden kelet-közép európai városban kimutathatók: az elöregedő lakosság mellett egy fiatalabb, jobb módú, mobilabb új réteg megjelenése, a lakófunkció visszaszorulása az irodák és szolgáltatások javára, a hagyományos helyi üzletek és szolgáltatók kiszorulása, a turisztikai és kulturális funkciók elterjedése, a szórakoztatóipar megjelenése vagy az épített környezet átalakulása - sok esetben a leromlott épuiletek teljes átalakításával. Ez a folyamat Nyugat-Európában és Észak-Amerikában a hatvanas években indult el, régiónkban azonban csak az 1990-es évek végétöl figyelhetö meg. A szerzők közül többen is megemlítik, hogy Kelet-Közép-Európában a dzsentrifikáció - egyelöre legalábbis - nem átfogóan érinti a vizsgált történelmi városrészek egészét, hanem pontszerủen: akár egy-egy háztömbre vagy utcára, akár néhány utca által közrefogott területre terjed ki (Budapest, Pozsony, Bukarest). Liviu Chelcea szerint már az is dzsentrifikációnak tekinthetö, amikor egy bukaresti utcának öt házából hármat az új tulajdonosok felújítottak, egyben egy szegény roma család lakik, az ötödik pedig romosan és üresen áll, a szomszéd utcában pedig kizárólag alacsony státuszú lakosság található.

A MOST-UNESCO program célkitúzése természetesen túlmutat a dzsentrifikáció jelenségének leírásán. A szerzök véleménye általában megegyezik abban, hogy a dzsentrifikáció egyirányú folyamat, amely számos társadalmi, politikai és gazdasági konfliktus forrása lehet. Ennek ellensúlyozásaképpen, a városnegyedek fenntartható revitalizációja érdekében további tényezők figyelembe vétele szuikséges, egyebek mellett az építészeti örökség és a helyi sajátosságok (üzletek, épületek, szokások) 
megóvása, az ott élő szegényebb rétegek érdekeinek védelme vagy a lakófunkció megtartása. Mindezek érdekében minden városban szükség volna a helyi önkormányzatok átfogó és átgondolt politikájára, mely mindenekelött a különbözö szereplök: beruházók, lakosság, érdekvédelmi szervezetek együttmüködésére épít. Ez az ,idilli” állapot azonban a vizsgált városokban egyelỏre nem tapasztalható.

Az egyes városokat elemző cikkek mindegyike alátámasztotta a konferencia bevezetö, elméleti előadásában Szirmai Viktória által levont következtetéseket, nevezetesen, hogy a kelet-közép európai városok sajátos fejlödése és problémái miatt a fenntartható társadalmi fejlődést elösegítő politikáknak és mozgalmaknak ebben a régióban még fontosabb szerepet kellene kapniuk, mint Nyugat-Európa vagy ÉszakAmerika városaiban.

A dzsentrifikáció mértéke és hatása természetesen a kelet-európai régióban is városonként eltérő. Annál is inkább, mert az egyes városokat elemző előadások $a$ „történelmi belváros" fogalmát eltéröen kezelik, és eltérő módszerekkel vizsgálják. Egyes esetekben a vizsgálatok lefedik a city és a belső városrészek egészét (Pozsony, Varsó), más esetekben egy-egy kiemelt városrésszel foglalkoznak (Krakkó, Bukarest, Budapest).

Prágában a vizsgált „történelmi belváros” területe megegyezik a nemzetközi turizmus által már a kilencvenes évek elején felfedezett városközponttal, így itt a városrész átalakulása, a lakófunkciók csökkenése, az új szolgáltatások megjelenése gyorsan ment végbe. A kilencvenes évek alatt kb. 15\%-kal csökkent a lakások száma, és ezzel párhuzamosan megfigyelhetö volt a lakosság csökkenése és elöregedése. Az ezredforduló táján viszont ez a csökkenés mérséklődni látszik: Prága belvárosában megjelentek az új lakók, a magasabb végzettségüek, tehetősebb és viszonylag nagy számban a külföldi, föleg nyugati országokból érkezett ideiglenes bevándorlók.

A Krakkót, Bukarestet és Budapestet tárgyaló esettanulmányok a történelmi belvárosok egy-egy jól lehatárolt egységét vizsgálják. Ezek a városrészek nem esnek egybe a ,city”-vel, vagyis a város gazdasági, politikai központját képezö területtel, hanem azon kívül helyezkednek el, azzal határosak. Kialakulásuktól fogva hagyományosan lakó- és helyi szolgáltatási funkciókat láttak el a városi kőzéprétegek számára, és így erös történelmi hagyományokkal és építészeti értékekkel rendelkeznek. Közös jegyük, hogy a második világháború előtt a zsidó népesség által lakott negyedekról (Budapest és Krakkó esetében a város „zsidó negyedéröl”) van szó, amelyeknek lakossága a Holokauszt és 1950-es évek kitelepitései után nagymértékben átalakult: a középosztály helyét a betelepített munkásság vette át. E városnegyedek egykori multikulturális szellemét azonban nemcsak az építészeti emlékek, zsinagógák, udvarok, táblák őrzik, hanem az is, ahogyan a kilencvenes évek átalakulása során egyszerre mintha ismét ráleltek volna egykori szellemükre. A budapesti és a krakkói zsidó negyedben ,egyedüli és mozgalmas hangulatú városrészek" kialakulása figyelhető meg, a városrész sajátos hangulatát kifejező alternatív mủvészkávézókkal, galériákkal, könyvesboltokkal, az ide költöző egyetemistákkal és müvészekkel. 
Pozsony esete a régióban szintén tipikus jelenséget mutatja be: azt, amikor legális, de inkább fél-legális megoldások segítségével a magán beruházók elképzelése és fejlesztése alapján alakul át a történelmi városnegyed.

A fenti tendenciák ugyan Nyugat-Európában, Észak-Amerikában vagy bármely további kontinensen is tapasztalhatók, a kelet-közép-európai városokban azonban e jelenségek sajátos vonásai mutathatók ki.

Az egymással szervesen összefüggő jelenségek közül nehéz kiválasztani a „legfontosabbat". A kelet-közép-európai városok sajátos földrajzi, morfológiai fejlödésen mentek keresztül. Ebben a régióban a városfejlödés első szakasza (a városrobbanás, azaz a város belső területeinek gyors benépesedése) utáni második, az agglomerálódás szakasza a nyugat-európai városokhoz képest csak későn, kb. az 1970-es években indult meg (Enyedi 1988). A tömeges szuburbanizáció jelensége azonban egyértelmúen a rendszerváltás utáni évekhez köthető: Budapesten az 1980-as évek végén, 1990-es évek legelején, más városokban (Pozsony, Kolozsvár) viszont ennél még később. A középosztály egy részének kiköltözése az egyre rosszabb lakókörülményeket nyújtó történelmi belvárosok területéról így szintén csak a kilencvenes évek elején indult meg. A népesség csökkenése és elöregedése ellenére ezek a városrészek megőrizték viszonylag magas népsürüségüket, $\mathrm{s}$ így bennük a dzsentrifikáció során felmerülö társadalmi konfliktusok is erőteljesen jelentkeznek.

Egy városrész dzsentrifikációja, azaz társadalmi-funkcionális átalakulása értelemszerủen a városrész ,identitását” is válságba sodorja. A vizsgált kelet-közép-európai városok történelmi belvárosai esetében ez a társadalmi összetétel átalakulásából eredő identitás-válság a kilencvenes évek dzsentrifikációs folyamatát azonban már jóval megelözte. Elég, ha Varsó, Krakkó, Prága, Budapest zsidó negyedeire gondolunk, hogy megértsük: ezekben a városokban a történelmi belvárosok többszörös társadalmi, funkcionális és sok esetben építészeti átalakuláson mentek keresztül. Az 1940-es és 1950-es évek után e negyedek városon belül elfoglalt szerepe átalakult: szomorú, elhagyatott, lepusztult, városrészekké váltak. A negatív megítélést alátámasztotta, hogy e városrészekbe a kommunista rendszer általában alacsony jövedelmủ rétegeket telepített (pl. Bukarest vizsgált negyedébe elsösorban roma családokat). A szocialista rendszer várospolitikája e városnegyedeket - tudatosan - elhanyagolta, a felújítási munkálatok elmaradtak, így a rendszerváltásra az omladozó épületek sok esetben életveszélyessé is váltak.

$\mathrm{Az}$ elvesztett identitás meglelése és a leromlott épített- és infrastrukturális környezet megújítása a rendszerváltás után a vizsgált városokban hasonló nehézségekbe ütközött.

Az első és legfontosabb nehézségként a szerzök a tulajdonviszonyok kuszaságát említik. Az ötvenes évek államosításai következtében a vizsgált városok történelmi negyedeiben a lakáspiac szinte teljes egészében állami tulajdon lett, a lakók állami bérlakásokban laktak. A rendszerváltás után a lakások privatizációja országonként eltérően zajlott ${ }^{8}$, de a városi társadalmi szegregáció erősödése mellett a tulajdonosi szerkezet bonyolult átalakulásához is vezetett, úgy, hogy sok esetben egy épületen belül is nehéz volt megállapítani a tulajdoni viszonyokat. A leromlott állapotú tör- 
Tér és Társadalom 20. évf. 2006/1. 147-163. p.

ténelmi belvárosok esetében az ingatlanok felújítását az összetett tulajdonosi viszonyok nehezítik, akár hosszú évekre ellehetetlenítik.

A közszféra szủk lehetőségei miatt a kelet-közép-európai régióban a városok fejlesztésében a magánszféra aránytalanul nagy szerepet kap. Ez a szerepkör sok esetben a várostervezésre, a szabályozás átalakítására is kiterjed. A magánszféra ugyanakkor értelemszerüen igyekszik a legkisebb befektetéssel a legnagyobb haszonra törekedni. Ez gyakran felemás, félkész városfelújítást, a városi tér átgondolatlan, oda nem illö, a társadalmi-politikai konszenzust teljes mértékben nélkủilözô átalakulását eredményezi. Jó példa erre, amikor a kilencvenes években a leromlott belvárosi épủletek földszintjén az üzlethelyiségek körüli falfelületet az üzletek tulajdonosai felújíttatták, míg a ház többi része továbbra is omladozott. A járókeló, ha nem nézett fel, akár egy elegáns nagyváros bevásárló utcájában is érezhette magát. (Ezt nevezte egy lengyel városkutató, Grzegorz Weçlawowicz „földszintes kapitalizmusnak”.)

A késói szuburbanizáció hatására a kilencvenes évek elején, vagyis a dzsentrifikációs folyamatok megindulásakor a vizsgált történelmi belvárosok népsürüsége különösen azon városrészek esetében volt magas, amelyek nem esnek egybe a város gazdasági, politikai és turisztikai központjaként szolgáló „,city”-vel. Mindegyik városban kimutatható ugyanakkor a történelmi városközpontban elö lakosság elöregedése, ill. számának csökkenése. Az 1990-es évek alatt betelepedỏ új réteg viszont leginkább fiatalokból, egyetemistákból, esetleg jómódú yuppiek-ból áll, akiknek szokásai, társadalmi kapcsolatrendszere és a városnegyedhez való kơtődése egészen más, mint az eredeti lakosságé. Mint Monika Murzyn cikkéböl kiderül, Krakkó egykori zsidó negyedében a lakók között a szocializmus alatt meglevő erős kapcsolattartás és összefogás (amely részben abból is eredt, hogy a városkörnyéket az egész város „lenézte”) megszúnt, és a helyét újfajta, elsősorban kereskedelmi és üzleti kapcsolatok vették át. Kazimierz negyedében - és ugyanez elmondható Budapest VII. kerületében található zsidó negyedre is - megjelentek az új beköltözők igényeit kielégítő kávézók és üzletek, melyeknek hatására az egykor zárt és lenézett városnegyed megnyílt a város egyéb részeiben lakók felé is. Az új kávézók és üzletek mủködtetői és látogatói szembekerülnek az eredeti helyi lakossággal (a zaj, a túlzottan pezsgó élet miatt), viszont a helyi lakossággal együtt kerülnek szembe azokkal nagy magán beruházókkal, akik a beruházás rentabilitása érdekében akár az eredeti épületek lebontásától és a városnegyed teljes átalakításától sem rettennek el. A krakkói példa tehát azt sugallja, hogy az egyes rétegek által képviselt társadalmi-gazdasági problémák egymásra rakódása újfajta helyi identitás kialakulásához is vezethet, ha megfeleló összefogás és konszenzus alakul ki az egyes csoportok között.

Többek között e konszenzus eléréséhez lenne szükséges a civil szervezetek megerősödése a régióban. Kelet-Közép-Európában, a civil szféra hagyományos gyengeségéből, ill. az anyagi lehetőségek hiányából eredően a társadalmi érdekvédő szervezetek lehetőségei egyelőre korlátozottak. A városok többségében megindult a történelmi belvárosok védelmére hivatott szervezetek kialakulása, ezek érdekérvényesítô ereje és eredményei városonként eltérőek. Pozsonyban a környezeti és polgári jogok védelmére létrejött civil szövetség sem volt képes rá, hogy megakadá- 
lyozza a 34 emeletes kereskedelmi beruházás megvalósulását a városközpontban. Budapesten az ÓVÁS Egyesület hosszas harcok után képes volt a Fövárosi Önkormányzat figyelmét felhívni az egykori zsidó negyed pusztulását elösegítő kerületi önkormányzati politika veszélyeire, és leállíttatni a további épületrombolások engedélyezését. Megemlítendő azonban, hogy a sikerpéldaként említett ÓVÁS egyesület is egyelöre korlátozott lehetőségekkel bír, hiszen elsősorban építészeti és örökségvédelmi szempontból közelíti meg a zsidó negyed dzsentrifikációjának problémáját. Az egyesület ugyanakkor folyamatosan tágítja kapcsolatait, amelyre példa a 2005 öszén megrendezett nemzetközi konferenciája is. Érdekes továbbá Monika Murzyn megjegyzése, miszerint Krakkó zsidó negyedének megóvásában a nemzetközi zsidó közösség semmilyen aktív szerepet nem vállalt, és eltekintve a felekezeti épületektől, nem vesz részt a városrész felújításában.

A civil szervezetek sikeressége és lehetőségei erösen függenek a helyi (városi) önkormányzatok hozzáállásától. A szerzök szinte kivétel nélkül felhívják a figyelmet arra, hogy a történelmi belvárosok társadalmilag fenntartható megújulásának egyik alapvető feltétele az átgondolt, az egyes szereplök együttműködését elösegítő önkormányzati politika.

A rendszerváltás után a közigazgatás decentralizációja, az állami tervezés megszünése, ill. bizonyos közfeladatok és köztulajdonok átruházása az újonnan létrehozott helyi önkormányzatok felé a kelet-közép-európai országokban a helyi politika szerepének növekedéséhez, esetenként meghatározóvá válásához vezetett. A helyi önkormányzatok ugyanakkor nélkülözték azokat az eszközöket, tapasztalatokat és politikai-történelmi hátteret, melyek meglétével elösegíthették volna a társadalmi konszenzuson alapuló fejlödést.

Egyes országokban (pl. Lengyelország és Magyarország) az 1980-as években megszülettek az első városrehabilitációs tervek, és elindultak az első programok. Ezek azonban akkor még az államszocializmus keretein belül zajlottak, s így a rendszerváltás után hamar megszüntek (Krakkóban a zsidó negyed felújítása már meg sem tudott indulni) vagy átalakultak (Budapesten a IX. kerület vegyes, magánönkormányzati rehabilitációja már a rendszerváltás után fejlődött ki). Az 1990-es évek elejétől a városfejlesztés sokszereplőssé vált, az önkormányzatok új szerepköreinek és módszereinek kialakítását azonban máig megnehezíti az anyagi lehetőségek hiánya. A minimális feladatok ellátása érdekében többségük még mindig elsősorban a gazdasági bevételeinek növeléséért küzd, és ez különösen igaz az alacsony státuszú városrészek esetében.

$\mathrm{Az}$ önkormányzat saját fejlesztési lehetőségeinek hiányában a leromló városrészek fellendítésére és egyben az önkormányzati bevételek növelésére a legkézenfekvőbb megoldásnak a magán befektetők vonzása bizonyult. A magán befektetök és az önkormányzatok között a viszony sokszor egyenlötlen: a szabályokat és feltételeket sokszor egyenesen az előbbiek szabják meg, de enyhébb esetben is, elöbbutóbb elérik eredeti befektetési céljukat. Pozsonyban a civil szervezetek tiltakozása ellenére az önkormányzat végül is engedélyezte, hogy a történelmi városközpontban, az örökségvédelem alá eső terület mellett egy eredetileg nyolc emeletes keres- 
kedelmi épület építési engedélyét módosítsák, és egy 34 emeletes épületet húzzanak fel. Mint később kiderült, a beruházó már akkor is a 34 emeletes épület alapjait ásta meg, amikor az engedély még csak nyolc emeletre szólt!

Az önkormányzat és általában a közszféra szerepének, gazdasági-politikai kapcsolatainak átláthatatlanságára az egyik legszélsőségesebb példát a bukaresti esettanulmány mutatja. Informális, gyakran illegális módon, régi kapcsolatok alapján, sok esetben a privatizációs törvények kiskapuinak kihasználásával szereztek tulajdont az egykor politikai befolyással bíró személyek Bukarest történelmi belvárosában. Liviu Chelcea cikkében az ingatlanszerzést és az ebböl eredő dzsentrifikációt az eredeti tökefelhalmozás poszt-szocialista változataként fogalmazza meg, azzal a sajátossággal, hogy Romániában a kilencvenes években az ingatlanszerzés alapja nem gazdasági, hanem elsősorban politikai-kapcsolati tőke volt.

Az önkormányzatok és a magánbefektetook erős függőségi viszonya mellett érthetö, hogy a kulturális örökség és a helyi értékékek védelméért küzdỏ civil szervezetek lehetőségei egyelöre korlátozottak. Mindamellett a 2000-es évek egyik legpozitívabb fejleményének a kelet-közép-európai régióban kétségtelenül a városi értékeket védelmező civil szervezetek létrejöttét tekinthetjük, és erröl a helyi politikának előbb-utóbb tudomást kell vennie. Az eddig vizsgált esetek közül azonban egyedül Budapesten akadt példa arra, hogy egy civil szervezet tevékenysége valós politikai eredményhez vezessen a városban, és a helyi politikai érdekekkel szemben képes legyen megakadályozni - vagy legalábbis felfüggeszteni - a történelmi belváros átformálását. (Ebben az esetben úgy tünik, a budapesti kétszintü oonkormányzati rendszer elönyös volt, hiszen lehetövé tette a Fövárosi Önkormányzat közbelépését a kerületi önkormányzattal szemben.)

A fenti példák mutatják, hogy a történelmi belvárosok fenntarthatósága távolról sem egy szerepló átgondolt politikájának függvénye. Az esettanulmányok arra is utalnak, hogy az interjúk, beszámolók vagy a sajtó alapján megismerhető ingatlanpiaci események mögött számos esetben olyan fél-legális vagy illegális érdekek és csoportok húzódnak, amelyeknek megismerésére egy szociológiai kutatás nem elegendő. Ezek a háttérben húzódó szereplők és érdekek alapvetően meghatározhatják egy városnegyed sorsát, akár minimálisra is szükíthetik a többi szereplö, így a helyi önkormányzat mozgásterét is.

Az angol nyelvü kötet számára eddig elkészült, a kelet-közép-európai városokat elemző esettanulmányok közül eddig egyedül Budapesttel kapcsolatban merültek fel olyan programok, amelyek önkormányzati részvétellel, kifejezetten a fenntartható városrehabilitáció elösegítése érdekében indultak meg, mint pl. a Magdolna-negyed felújítása. A történelmi belvárosok fenntarthatóságának problémája ugyanakkor már több város önkormányzatának fejlesztési stratégiájában is megjelent: Krakkóban egy külön csoportot állítottak fel a zsidó negyed fejlesztési stratégiájának kidolgozásához, Budapesten a városrehabilitáció lett a Podmaniczky-terv egyik alappillére. 
Tér és Társadalom 20. évf. 2006/1. 147-163. p.

A székesfehérvári konferencia, valamint az ott elhangzott előadások és további esettanulmányok alapján elkészülö angol nyelvü kiadvány a fenntartható városrehabilitáció már sokat tárgyalt kérdéséről kíván átfogó képet adni. Újdonsága, hogy a problémát regionális szinten tárgyalja, és igyekszik a kelet-közép-európai országok nagyvárosaira közösen jellemzô sajátosságokat megállapítani. Bár a cikk elején már említett két nem poszt-szocialista városról ebben az összefoglalásban nem esett szó, Bécs városának ,soft” rehabilitációs programja, ill. Lyon belvárosi munkás-negyedének rehabilitációja szintén számos tanulsággal szolgál majd a városrehabilitációval foglalkozó kelet-közép-európai szakemberek számára.

\section{Jegyzetek}

${ }^{1}$ A konferencia szervezöi: Prof Enyedi György, A MOST-UNESCO Magyarországi Bizottsága elnöke, akadémikus, MTA/VITA Alapívány; Hervainé Dr Szabó Gyöngyvér, Kodolányi János Főiskola; Prof Szirmai Viktória, MTA Szociológiai Intézet és MTA-RKK; Baráth Gabriella, MTA-RKK; Borgos Györgyné, MTA/VITA Alapítvány; Dr Keresztély Krisztina, MTA/VITA Alapítvány és MTA-RKK.

${ }^{2}$ A konferencia kúlföldi elöadói: Prof Heinz Fassmann, Bécs;

Prof Tomás Kucera, Prága;

Prof Jan Bucek, Pozsony;

Prof Mariusz Kowalski, Varsó;

Dr Anka Misetic, Zágráb;

Dr Benedek József, Kolozsvár.

Megfigyelö meghívottként vett részt Mr Bruno Voisin, Lyonbót. A magyar elöadók:

Gresiczky Péter, a Magyar UNESCO Bizottság fötitkára;

Prof Enyedi György, a MOST-UNESCO Magyarországi Bizottsága elnöke, akadémikus;

Prof Szirmai Viktória, MTA Szociológiai Intézet és MTA-RKK;

Dr Horváth M. Tamás, Magyar Közigazgatási Intézet;

Warvasovszky Tihamér, Székesfehérvár polgármestere;

Prof Kovács Zoltán, MTA Földrajztudományi Intézet;

Ongjerth Richárd, Studio Metropolitana Városkutató Intézet.

${ }^{3}$ Baltimore, Budapest, Genf, Fokváros, Lyon, Miami, Montréal, Nairobi, San Salvador, Sao Paulo, Toronto és Utrecht.

${ }^{4}$ A két kézikönyv: Polese - Stern (eds) (2000) The Social Sustainability of Cities: Diversity and Management of Change, és Bailly-Brun-Lawrence-Rey (eds) (2000) Développement social durable des villes - principes et pratiques. Anthropos, Paris.

${ }^{5}$ Budapest, Fokváros, Genf, Lyon, San Salvador és Rotterdam.

${ }^{6}$ Enyedi (szerk.) (2004) Public participation in Socially Sustainable Urban Development. UNESCO MTA-RKK - MTA/VITA Alapítvány, Pécs.

${ }^{7}$ Idézet Kovács Zoltán tanulmányából.

${ }^{8}$ Az országok többségére a teljes kártérítés gyakorlata a jellemző, vagyis az egykori tulajdonosok, ill. azok leszármazottai egy az egyben visszakapták egykori ingatlanukat, azzal a feltétellel, hogy a bérlakókat nem költöztethették ki a lakásból. Erre természetesen voltak kiskapuk, pl. ha egy másik, hasonló méretủ és adottságú lakást találnak az új tulajdonosok a régi bérlönek. Magyarországon a kárpótlási folyamat inkább a szocializmus végére kialakult helyzetet vette figyelembe, amikor nem alkalmazta a teljes kárpótlás módszerét, hanem a lakásokat a helyi önkormányzatoknak adta át, és lehetóvé tette a lakások kedvezményes áron való megvásárlását. 


\section{Irodalom}

Bailly, A.-Brun, Ph.-Roderick, J.L.-Rey, M.-C. (2000) Développement Social Durable des villes. Anthropos, Paris.

Enyedi Gy. (1988) A városnövekedés szakaszai. Akadémiai Kiadó, Budapest.

Enyedi Gy. (szerk.) (2004) Public Participation in Socially Sustainable Urban Development. MTA/VITA - MTA-RKK - MOST-UNESCO, Pécs.

\section{Elöadások:}

Szirmai Viktória: „Social Sustainability in Central European Cities”

Horváth M. Tamás: „Problems related to Public Administration of Budapest”

Tomás Kučera: „Urban Renewal and Functional Transformation in the Historical Centre of Prague”

Mariusz Kowalski: „Problems of Social Development in Warsaw City Centre"

Jan Buček: „Managing Post-Socialist Urban Transformation. Case Study of Bratislava and its City Centre"

Heinz Fassmann: „Urban Renewal Policy in Vienna”

Anka Miśetić: "Social Aspects of Life in the Inner City of Zagreb”

Warvasovszky Tihamér. „Problems of Social Sustainability in the Historical Inner City of Székesfehérvár"

Kovács Zoltán: „Social and Economic Transformation in the Inner City of Budapest”

Ongjerth Richárd: „Social Aspects of Urban Renewal Programs in Budapest”

Enyedi György: „Conclusions”

\section{Kéziratok:}

Benedek József: „Social Sustainability in the Historical Disctrict of Cluj”

Jan Buček: „Post-socialist Urban Development, Planning and Participation - The Case of Bratislava City Centre"

Liviu Cheicea: „Marginal Groups in Central Places: Gentrification, Property Rights and Post-socialist Primitive Accumulation (Bucharest, Romania)"

Kovács Zoltán: „Social and Economic Transformation of Historical Districts in Budapest”

Mariusz Kowalski: „Problems of Socio-Spatial Development of Dowtown Warsaw”

Monika Murzyn: „Winners and Losers" in the Game. Social Dimension of Urban Regeneration in the Kazi mierz quarter in Cracow"

Bruno Voisin: „Tertiarization, gentrification and marginalization. The Voltaire district in Lyon (France)” 
Tér és Társadalom 20. évf. 2006/1. 147-163. p. 